\title{
THE STUDY OF THE AMINO ACID COMPOSITION OF THE EXTRACTS OBTAINED FROM CHERRY LEAVES AND SHOOTS, LEAVES OF APRICOT AND PEACH
}

\author{
L.V.Lenchyk \\ National University of Pharmacy
}

Key words: aminoacids; cherry; peach; apricot; HPLC

\begin{abstract}
The extracts have been obtained from the raw material of cultivated plants from Rosaceae family, and their pharmacological screening has been carried out. It has been found that the extract of cherry shoots shows the diuretic activity that is higher than the activity of the reference drug hypothiazide in the dose of $100 \mathrm{mg} / \mathrm{kg}$, the extracts from cherry and apricot leaves possess a significant anti-inflammatory activity in the dose of $25 \mathrm{mg} / \mathrm{kg}$, and the extract from peach leaves shows the immunotropic activity in the low concentration of $0.4 \mathrm{mg} / \mathrm{ml}$ detected in vitro. These extracts are promising for further study and creation of new medicines on their basis. The composition and content of free amino acids in the dry extracts obtained from leaves and shoots of cherry, leaves of apricot and the soft extract from peach leaves have been determined by HPLC. The presence of 21 amino acids has been identified; among them eight acids - threonine, valine, isoleucine, leucine, phenylalanine, histidine, lysine and arginine are essential. Proline, asparagine, $\gamma$-aminobutyric and glutamic acids, arginine and alanine prevail. All extracts are free of cystine and methionine, and only extracts from leaves of cherry and peach contain cysteine in small amount. The dry extract of cherry shoots possesses the highest amount of amino acids - $3154.2 \mathrm{mg} / \mathrm{L}$, the lowest content is in the extract from apricot leaves $-605.9 \mathrm{mg} / \mathrm{L}$.
\end{abstract}

In nature there are a great number of amino acids found in a free state, as well as components of proteins, peptides, enzyme systems, hormones, etc. They can form complexes with other compounds and thus affect their bioavailability and pharmacological effect. Amino acids, their derivatives and products of metabolism are widely used in medicine. For example, the use of arginine amino acid improves the condition of patients after a stroke, $\gamma$-aminobutyric acid relieves agitation and has a calming effect, it is used in the complex treatment of epilepsy and hypertension; asparagine is required for normal functioning of the nervous system $[1,4]$.

In recent years the extracts from apricot and peach leaves, cherry shoots and leaves were obtained at the Department of Chemistry of Natural Compounds of the National University of Pharmacy, and their pharmacological screening was carried out. It has been found that the extract of cherry shoots shows the diuretic activity that is higher than the activity of the reference drug hypothiazide in the dose of $100 \mathrm{mg} / \mathrm{kg}$, the extracts from cherry and apricot leaves possess a significant anti-inflammatory activity in the dose of $25 \mathrm{mg} / \mathrm{kg}$, and the extract from peach leaves shows the immunotropic activity in the low concentration of $0.4 \mathrm{mg} / \mathrm{ml}$ detected in vitro [5-10].

The substances obtained are promising for further study and creation of new medicines on their basis.

The aim of our research was a comparative study of the amino acid composition of the extracts obtained from leaves and shoots of cherry, leaves of apricot and peach.

\section{Materials and Methods}

The objects of our study were dry extracts from cherry leaves and shoots, apricot leaves and the soft extract from peach leaves. The extracts were obtained by exhaustive extraction with low concentrations of ethyl alcohol.

Determination of the composition and content of free amino acids in the extracts obtained was studied using an Agilent Technologies high performance liquid chromatograph (model 1100) equipped with a continuous-flow vacuum degasifier G1379A, a 4-channel pump of the low pressure gradient G13111A, an automatic injector G1313A, a column oven G13116A, a diode array detector G1316A. The ZORBAX-XDB-C18 chromatographic column, $4.6 \times 50 \mathrm{~mm}$, filled with the octadecyl silyl sorbent with the grain size of $1.8 \mu \mathrm{m}$ was used for analysis $[2,3]$.

Determination was carried out by the following procedure.

In a $10 \mathrm{ml}$ vial place $0.3 \mathrm{~g}$ of the extract (accurate weight), and add $3 \mathrm{ml}$ of $0.1 \mathrm{~N}$ hydrochloric acid aqueous solution containing $0.2 \% \beta$-mercaptoethanol. Seal the vial and keep in an ultrasonic bath at $50^{\circ} \mathrm{C}$ for $2 \mathrm{~h}$. Centrifuge the content of the vial and filter through a Teflon membrane filter with the pore size of $0.45 \mu \mathrm{m}$ in a vial for analysis.

Take $100 \mu 1$ of the filtrate into a vial placed in a vacuum desiccator at $40-45^{\circ} \mathrm{C}$ and the pressure of $1.5 \mathrm{~mm}$ $\mathrm{Hg}$ to remove hydrochloric acid completely. Then add $200 \mu \mathrm{l}$ of $0.8 \mathrm{M}$ borate buffer with $\mathrm{pH} 9.0$ and $200 \mu \mathrm{l}$ of $20 \mathrm{mM}$ solution of 9-fluorenylmethoxycarbonyl chloride in acetonitrile in a vial for analysis consistently with the automatic dispenser and after 10 min exposure add $20 \mu 1$ of $150 \mathrm{mM}$ solution of amantadine hydrochloride in $50 \%$ aqueous acetonitrile to the reaction mixture.

Analysis was performed under the following conditions: the chromatographic linear gradient, the operating pressure of the eluent $-220-275 \mathrm{kPa}$, the thermostat 
The amino acids composition of the extracts obtained from cherry leaves and shoots, apricot and peach leaves

\begin{tabular}{|c|c|c|c|c|}
\hline \multirow[b]{2}{*}{ Amino acids } & \multicolumn{4}{|c|}{ Content, (mg/L) } \\
\hline & 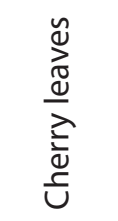 & 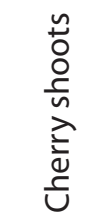 & 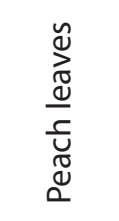 & 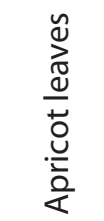 \\
\hline Aspartic acid & 34.9 & 19.8 & 55.4 & 18.9 \\
\hline Glutamic acid & 250.6 & 56.3 & 41.9 & 10.4 \\
\hline 4- Hydroxyproline & 20.5 & 30.1 & 20.6 & 15.8 \\
\hline Asparagine & 105.5 & 138.9 & 195.5 & 114.0 \\
\hline Glutamine & 87.3 & 41.3 & 7.6 & 13.1 \\
\hline Serine & 33.0 & 30.2 & 33.9 & 14.9 \\
\hline Arginine & 64.7 & 887.6 & 71.4 & 37.2 \\
\hline Glycine & 27.2 & 47.3 & 14.4 & 13.0 \\
\hline Threonine & 26.1 & 83.7 & 17.2 & 14.6 \\
\hline Alanine & 83.8 & 178.1 & 169.1 & 36.7 \\
\hline Proline & 361.2 & 880.7 & 1439.0 & 141.3 \\
\hline$Y$-Aminobutyric acid & 212.1 & 404.7 & 185.3 & 69.3 \\
\hline Valine & 23.7 & 48.2 & 41.2 & 10.5 \\
\hline Methionine & 0.0 & 0.0 & 0.0 & 0.0 \\
\hline Isoleucine & 37.7 & 53.3 & 39.8 & 5.6 \\
\hline Leucine & 14.1 & 61.9 & 21.2 & 9.2 \\
\hline Phenylalanine & 15.9 & 48.6 & 68.4 & 10.5 \\
\hline Monoethanolamine & 45.2 & 54.5 & 19.1 & 24.1 \\
\hline Cystine & 0.0 & 0.0 & 0.0 & 0.0 \\
\hline Histidine & 17.9 & 29.3 & 7.0 & 22.3 \\
\hline Lysin & 7.4 & 53.2 & 10.0 & 15.6 \\
\hline Cysteine & 5.4 & 0.0 & 1.9 & 0.0 \\
\hline Tyrosine & 24.0 & 6.9 & 0.0 & 8.8 \\
\hline Total & 1498.4 & 3154.2 & 2460.0 & 605.9 \\
\hline
\end{tabular}
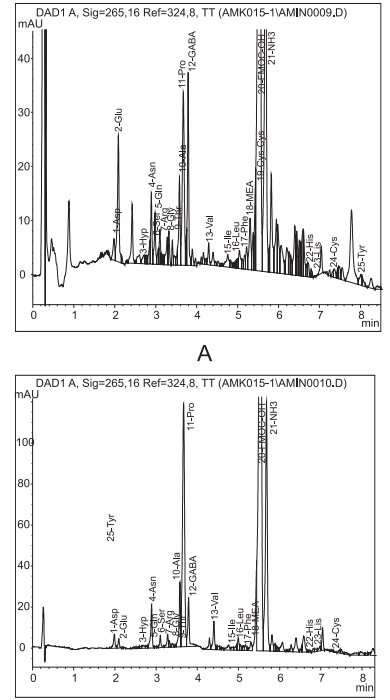

C

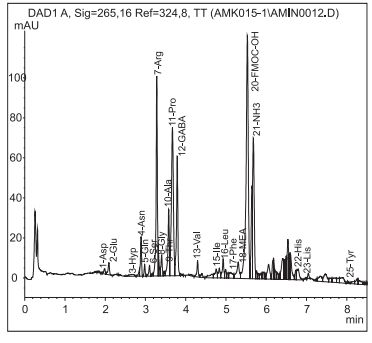

B

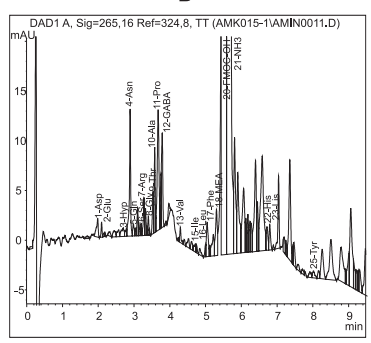

D
Fig. The chromatograms obtained when determining the content of free amino acids in the extracts from: $A$ - cherry leaves, $\mathrm{B}$ - cherry shoots, $\mathrm{C}$ - peach leaves, D - apricot leaves. temperature $-50^{\circ} \mathrm{C}$, the sample volume $-2 \mu \mathrm{l}$. Detection parameters were as follows: the scale of measurement -1.0 ; the scan time $-0.5 \mathrm{~s}$; the detection wavelength $-265 \mathrm{~nm}$, the mobile phase flow rate $-1.5 \mathrm{ml} / \mathrm{min}$, and from the 10 -th $\mathrm{min}-2 \mathrm{ml} / \mathrm{min}$. As a mobile phase $0.05 \mathrm{M}$ and $0.10 \mathrm{M}$ aqueous solutions of sodium acetate were used. From 8.47 to $10 \mathrm{~min}$ water and acetonitrile were used, and from 10.10 to 11 min sodium acetate solutions were used again.

To obtain statistically valid data the tests were carried out three times. Standard solutions of amino acids were used in quantitative determination (Technical Specifications 6-09-3147-83). Identification of amino acids was performed by retention time of standards.

\section{Results and Discussion}

The results of qualitative and quantitative analysis of free amino acids in the extracts are shown in Table, chromatograms are given in Fig.

As can be seen from Table, the total content of free amino acid was the highest in the extract obtained from cherry shoots, and the extract obtained from apricot leaves had the lowest amount.

If we compare the total content of amino acids in the extracts from peach leaves and apricot leaves, the content of amino acids in the extract from peach leaves was four times higher than in the apricot extract. The content of free amino acids in the extract from cherry shoots was twice higher than in the extract from cherry leaves. Of all the amino acids the proline content was the highest in the extract from peach leaves, and it was $1439.0 \mathrm{mg} / \mathrm{L}$.

As a result of our study it has been found that there are 21 amino acids in the extract from cherry leaves and 20 - in the extract from cherry shoots; 20 amino acids have been found in the extracts from apricot leaves and peach leaves each. The content of proline, glutamic and $\gamma$-aminobutyric acids was the highest in the extract from cherry leaves. The content of arginine, proline and $\gamma$-aminobutyric acid was the highest in the extract from cherry shoots. The content of proline was also the highest in the extract from peach leaves, and the content of asparagine and $\gamma$-aminobutyric was significant as well. In the extract from apricot leaves the content of proline, asparagine and $\gamma$-aminobutyric acid dominated. Thus, it has been found that the content of proline, asparagine, $\gamma$-aminobutyric acid, arginine, glutamic acid, alanine is significant or the highest in all extracts under study. Among the essential amino acids the content of arginine was rather significant in all extracts, and all extracts contained such essential amino acids as threonine, valine, isoleucine, leucine, phenylalanine, histidine and lysine. Cystene and methionine were not determined in all extracts; whereas small quantities of cysteine were found only in the extracts of cherry and peach leaves.

CONCLUSIONS

The amino acid composition of dry extracts from cherry leaves and shoots, apricot leaves and the soft extract from peach leaves has been studied. The composition and content of the amino acids have been determined. The presence of 21 amino acids has been identified; among them eight acids - threonine, valine, isoleucine, leucine, phenylalanine, histidine, lysine and arginine are essential. Proline, asparagine, $\gamma$-aminobutyric and glutamic acids, arginine, alanine prevail. 


\section{REFERENCES}

1. Egebjerg J., Schousboe A., Krogsgaard-Larsen P. Glutamate and GABA Receptors and transporters; Structure, Function and Pharmacology. - London: Taylor and Francis, 2002. - P. 287-304.

2. Jámbor A., Molnár-Perl I. // J. of Chromatography A. - 2009. - Vol. 1216. - P. 6218-6223.

3. Jámbor A., Molnár-Perl I. // J. of Chromatography A. - 2009. - Vol. 1216. - P. 3064-3077.

4. Koga Y., Akita Y., Junko N. et al. // Neurol. - 2006. - Vol. 66, №11. - P. 1766-1769.

5. Kravchenko A.B., Fayzullin A.V., Puzak O.A. et al. // Ukr. J. of Clin. and Laboratory Medicine. - 2009. - Vol. 4, №4. - P. 44-46.

6. Kyslychenko V.S., Lenchyk L.V., Navruzova G.F. The 15-th International Congress of the International Society for Ethno-Pharmacology (05-08 May, 2015, Petra-Jordan). - Petra, 2015. - P. 114-115.

7. Popovich V.P., Upyr L.V., Kyslychenko V.S. // Actual problems of theoretical, clinical, preventive medicine, dentistry and pharmacy: Mater. of the 72-th Intern. Sci. Conf. of Students and Young Scientists. - Donetsk, 2010. - P. 280-281.

8. Puzak O.A., Upyr L.V., Kyslychenko V.S. et al. // Pharmacy of Kazakhstan: integration of science, education and industry: Mater. of the Intern. Sci.-Pract. Conf. - Shymkent, Kazakhstan. - 2009. - Vol. 1. - P. 267-270.

9. Shtroblia A.L., Fira L.S., Kyslychenko V. S. et al. // Achievements of Clinical and Experimental Medicine. 2011. - №1. - P. 110-113.

10. Voronina L.M., Kravchenko G.B., Zagaiko A.L. et al. // News of Pharmacy. - 2010. - №1. - P. 66-68.

\section{ВИВЧЕННЯ АМІНОКИСЛОТНОГО СКЛАДУ ЕКСТРАКТІВ, ОТРИМАНИХ 3 ЛИСТЯ ТА ПАГОНІВ ВИШНІ, ЛИСТЯ АБРИКОСА ТА ПЕРСИКА \\ Л.В.Ленчик \\ Ключові слова: амінокислоти; вишня; персик; абрикос; ВEPX}

3 сировини культивованих рослин родини Rosaceae були отримані екстракти та проведено їх фрармакологічний скринінг. Виявилося, що екстракт пагонів вишні виявляв діуретичну активність в дозі 100 ме/ке, вищу за препарат порівняння гіпотіазид, протизапальна активність екстрактів з листя вишні та абрикоса у дозі 25 мә/ка була значною, екстракт з листя персика мав імунотропну активність, виявлену in vitro у низькій концентрації 0,4 мг/мл. Отримані субстанції є перспективними для подальшого вивчення та створення на їх основі нових лікарських засобів. Методом ВЕРX досліджено склад і вміст вільних амінокислот у сухих екстрактах, отриманих з листя та пагонів вишні, листя абрикоса, та в густому екстракті з листя персика. Встановлено наявність 21 амінокислоти, серед яких вісім є незамінними - треонін, валін, ізолейцин, лейцин, феенілаланін, гістидин, лізин і аргінін. Превалюють пролін, аспарагін, у-аміномасляна та глутамінова кислоти, аргінін, аланін. В усіх екстрактах не було виявлено цистину та метіоніну, а цистеїн містився тільки в екстрактах з листя вишні та персика у незначній кількості. Найбільшим був вміст амінокислот у сухому екстракті з пагонів вишні - 3154.2 мг/л, найменшим - у екстракті з листя абрикоса - 605.9 мг/л.

\section{ИЗУЧЕНИЕ АМИНОКИСЛОТНОГО СОСТАВА ЭКСТРАКТОВ, ПОЛУЧЕННЫХ ИЗ ЛИСТЬЕВ И ПОБЕГОВ ВИШНИ, ЛИСТЬЕВ АБРИКОСА И ПЕРСИКА Л.В.Ленчик \\ Ключевые слова: аминокислоты; вишня; персик; абрикос; ВЭЖХ}

Из сырья культивируемых растений семейства Rosaceae были получены экстракты и проведен их фрармакологический скрининг. Оказалось, что экстракт побегов вишни проявлял диуретическую активность в дозе 100 мг/ка, что выше чем у препарата сравнения гипотиазида, противовоспалительная активность экстрактов из листьев вишни и абрикоса в дозе 25 мә/ка была значительной, экстракт из листьев персика имел иммунотропную активность, установленную in vitro в низкой концентрации 0,4 ме/мл. Полученные субстанции являются перспективными для дальнейшего изучения и создания на их основе новых лекарственных средств. Методом ВЭЖХ исследован состав и содержание свободных аминокислот в сухих экстрактах, полученных из листьев и побегов вишни, листьев абрикоса и в густом экстракте из листьев персика. Установлено наличие 21 аминокислоты, среди которых восемь являются незаменимыми - треонин, валин, изолейцин, лейцин, фенилаланин, гистидин, лизин и аргинин. Превалируют пролин, аспарагин, $\gamma$-аминомасляная и глутаминовая кислоты, аргинин, аланин. Во всех экстрактах не обнаружены цистин и метионин, а цистеин содержался только в экстрактах из листьев вишни и персика в незначительном количестве. Самым высоким было содержание аминокислот в сухом экстракте из побегов вишни - 3154.2 мг/л, а наименьшим - в экстракте из листьев абрикоса - 605.9 мг/л. 